\title{
Assessement Of Socioeconomic Factors On The Adoption Of Improved Cowpea Production Technologies Among Farmers In Damaturu Local Government Area, Yobe State, Nigeria
}

\author{
Mohammed, N ., Abubakar, M. I' ${ }^{2}$, Abdul'aziz, M. A ${ }^{3}$., Kolo, M. K ${ }^{1}$ and Saje, A. B ${ }^{1}$ \\ ${ }^{1}$ Department of Agricultural Technology, Yobe State College of Agriculture, Science and Technology Gujba, Nigeria \\ ${ }^{2}$ National Agricultural Extension and Liaison Services, Ahmadu Bello University Zaria, Nigeria \\ ${ }^{3}$ Department of Basic Science Technology, Yobe State College of Agriculture, Science and Technology Gujba, Nigeria
}

DOI: 10.29322/IJSRP.12.01.2022.p12142

http://dx.doi.org/10.29322/IJSRP.12.01.2022.p12142

Abstract- The study assessed the influence of socioeconomic
factors on the adoption of cowpea production technologies
among farmers in Damaturu Local Government Area, Yobe
State, Nigeria. The specific objectives were to describe the socio- Inde
economic characteristics of farmers; assess the rate of adoption
of cowpea production technologies by farmers; determine the
socioeconomic factors that influenced the rate of adoption of
improved cowpea production technologies. Data for the study
were obtained from 100 sampled respondents through structured
questionnaire. The sampled respondents were selected through

environment free from any treat to carry out their farming operation effectively.

Index Terms- Adoption, Socioeconomic, Cowpea Production, Technology, Farmers

\section{INTRODUCTION} he relevance of technology to agricultural development especially in less developed countries is widely recognized based on its observed impact and potential towards contribution to the development of agriculture in the world. In developing countries like Nigeria where a greater proportion of the population live in rural areas, agricultural technology could provide a potential means of increasing production and subsequently raising income of the farmers as well as their living standard (Ani, 2013 cited in Yindau, 2014).

Cowpea (Vigna unguiculata L. Walp) belongs to the family "Fabaceae" which is an annual herbaceous legume from the genus Vigna. Due to its tolerance for sandy soil and low rainfall it is an important crop in the semi-arid regions across Africa (Singh et al., 1997). It requires very few inputs, as the plant's root nodules are able to fix atmospheric nitrogen, making it a valuable crop for resource poor farmers and well-suited to intercropping with other crops. The whole plant is used as forage for animals ( Paramu and Ning, 2017).

Cowpea is known by other names such as black eye beans, china beans, black eye pea and marble beans. Cowpea is one of the most ancient human staple foods and has probably been used as a crop since Neolithic times. It has been domesticated in Africa. The region of genetic diversity of cowpea is considered to be Nigeria; with an estimated production of 2.17 million tons per annum. The northern region of Nigeria produces about 1.7 million tons from about 4 million hectares, which represents over $60 \%$ of total national production (FAO, 2014). The crop was introduced to tropical America in 17th century by the Spanish and widely grown in the United States of America, the Caribbean region and Brazil (Izge et al., 2009). Cowpea is one of the most important economic crops in the tropics based on the fact that the 
whole plant parts are useful for human consumption and provision of livestock feed (FAO, 2014).

The crop has a protein content of $25 \%$; cowpea remains one of the cheapest sources of protein in the diet of many Nigerians (IITA, 2009). The crop tolerates drought and performs well in a wide variety of soil. Moreover, the bacteria in the root nodules contribute to soil fertility through nitrogen fixation in the soil and production of organic matter contents (Tijjani et al., 2015). As such, cowpea is broadly cultivated around the world. In most rural areas of Nigeria, cowpea farmers were experiencing problems associated with its production. These have an effect on the production capacity of cowpea farmers and their income. It is also observed that farmers often had access to improved cowpea production technologies as an avenue to reduce some of these short falls but to no avail.

However, rates of technology adoption by small-scale farmers were not as encouraging as expected. Despite the potential benefits it posses to increased cowpea production, farmers most often reject proven technologies that can increase their farm outputs. These necessitate for the need to analyze the factors that contributes or influence the rate of adoption of cowpea production technologies by farmers. Therefore, the study sought to assess the socioeconomic factors on the adoption of improved cowpea production technologies among farmers in Damaturu Local Government Area, Yobe State, Nigeria. The specific objectives were to:

i. describe the socio-economic characteristics of farmers in the study area;

ii. examine the rate of adoption of cowpea production technologies by farmers;

iii. determine the socioeconomic factors that influenced the rate of adoption of improved cowpea production technologies.

\section{METHODOLOGY}

\section{The Study Area}

The study was conducted in Damaturu Local Government Area, Yobe State, Nigeria. Its headquarters is in the town of Damaturu, the state capital. The area has an equal latitude and longitude of $12^{\circ} 00^{\prime} 00 \mathrm{~N} 12^{\circ} 00^{\prime} 00 \mathrm{E} / 12.00000^{\circ} \mathrm{N} 12.00000^{\circ} \mathrm{E}$ of the Greenwich Meridian with a postal code of 620 . The area has an annual rainfall of $649 \mathrm{~mm} / 25.6$ inch with an initial Temperature of $25.2^{\circ} \mathrm{C} / 77.4^{\circ} \mathrm{F}$. (Goggle map, 2018). It shares border with Borno State to the East, Fune LGA to the West, Tarmuwa LGA to the North and Gujba LGA to the south. It has an area of $2,366 \mathrm{~km}^{2}$ with a population of 388,014 (NPC, 2006). The population of the LGA is unevenly distributed with Damaturu town being the most populated area. Farming and animal rearing are the main occupations of the area.

\section{Sampling Technique and Sample Size}

A multi-stage sampling technique was employed in selecting the respondents. In the first stage, purposive sampling technique was used to select two (2) Agricultural blocks available in the Local Government Area, these are; Damaturu and Sassawa. In the second stage, two (2) cells were selected from each of the selected Agricultural blocks through a simple random sampling technique to give a total of four (4) cells. The sampled cells were Kukareta, Marfakalam, Damakasu, Kabam.
In the third stage, twenty five (25) farmers were selected from each of the sampled cells at random from the sampling frame of cowpea farmers in the area to give a total of one hundred (100) farmers that were considered for the study.

\section{Sources of Data}

The study used both primary and secondary data. Primary data were obtained from respondents with the use of structured questionnaires and interview schedule techniques while secondary data was obtained from articles, journals, publications, IFAD, YOSADP, IITA and ICRISAT.

\section{Analytical Techniques}

Both descriptive and inferential statistics were used to analyze the objectives of the study. Descriptive statistics such frequency count, percentages and mean were used to analyze objectives i, and ii. Inferential statistics such as Tobit multiple regression analysis was used to analyze the influence of socioeconomic factors on the adoption of improved cowpea production technologies by the respondents (i.e. objective iii). The Tobit regression model is appropriate when analyzing socioeconomic factors that influence level of technology adoption. The explicit Tobit regression is expressed as:

$\mathrm{Y}=\mathrm{a}+\mathrm{b}_{1} \mathrm{x}_{1}+\mathrm{b}_{2} \mathrm{x}_{2}+\mathrm{b}_{3} \mathrm{x}_{3}+\mathrm{b}_{4} \mathrm{x}_{4}+\mathrm{b}_{5} \mathrm{x}_{5}+\mathrm{b}_{6} \mathrm{x}_{6}+\mathrm{b}_{7} \mathrm{x}_{7}+\mathrm{b}_{8} \mathrm{x}_{8}+\mathrm{b}_{9} \mathrm{x}_{9}+\mathrm{b}_{10} \mathrm{x}_{10}+\mathrm{u}$

Where, (i)

$\mathrm{Y}=$ level of adoption measured in percentage (\%) of technologies adopted.

The variables estimated in the model include:

$\mathrm{X}_{1}=$ Age (in years)

$\mathrm{X}_{2}=$ Gender $($ Male $=1$, Female $=0)$

$\mathrm{X}_{3}=$ Marital status (Married $=1$, Single $=0$ )

$\mathrm{X}_{4}=$ Educational background (number of years in school)

$\mathrm{X}_{5}=$ Farm size (hectares)

$\mathrm{X}_{6}=$ Household size (number of household)

$\mathrm{X}_{7}=$ Annual farm income (in Naira)

$\mathrm{X}_{8}=$ Access to credit $($ Access $=1$, Otherwise $=0)$

$\mathrm{X}_{9}=$ Farming experience (number of years in cowpea production)

$X_{10}=$ Access to extension agents (number of visits in 2020)

$\mathrm{X}_{1}-\mathrm{X}_{10}=$ Independent variables

$b_{1}-b_{10}=$ Regression coefficients

$\mathrm{u}=$ Error term

\section{RESULTS AND DISCUSSION}

\section{Socio-economic Characteristics of the Respondents}

The socio-economic characteristics of the respondents considered for this study includes; age, gender, marital status, educational background, farm size, household size, annual farm income, access to credit, farming experience and access to extension agents. These are presented in Table 1.

\section{Age}

The above table discussed the socio-economic characteristics of the respondents. Age determines to some extend how productive an individual is in carrying out agricultural activities. The result for the age of the respondents shows that $80.0 \%$ of the respondents were within the age 
category of 31-40years, thus they are said to be in their productive age. This finding is similar to that of Ibrahim et al. (2016), which indicate that average age had greater tendency to adopt new innovations because they are more open to risk taking and have a longer planning horizon. Asiabaka et al. (2001) reported that farmer's ability to utilize new agricultural information on farm innovation decreases with age. The older the farmer is the less he/she likely to adopt

\section{Gender}

The result indicates that majority $(89.0 \%)$ of the respondents were male while $11.0 \%$ were female. This implies that most cowpea farmers in the study area were male. This finding agrees with the findings of Tiamiyu et al. (2013), who reported that cowpea production was dominated by men. This could be attributed to the fact that cowpea production is labor intensive especially for females who have numerous off farm or domestic activities apart from their engagements into farming.

\section{Marital status}

The marital status of the respondents revealed that $80.0 \%$ of cowpea farmers were married while others were single $(11.0 \%)$, divorced $(4.0 \%)$ and widowed $(7.0 \%)$ respectively. This implies that majority of the respondents were married and has a lot of responsibilities that made them to adopt an improved technologies in order to provide the basic necessity of life. This finding supported the work of Abah and Tor, (2012) who found out that most of the cowpea farmers in Lafia Local Government, Nasarawa State, Nigeria were married and thus has implication on adoption of agricultural technologies.

\section{Educational background}

The educational background of the respondents revealed that $48.0 \%$ had no formal education, $35.0 \%$ had primary education, $13.0 \%$ had secondary education and $4.0 \%$ had tertiary education. This indicates that $52.0 \%$ of the respondents were literate. This implies that there is potential for increased cowpea production since education enable farmers to have access to information on new Agricultural innovation which can be adopted to enhance their productivity (IITA, 2009). The low proportion of illiterates in the respondents' group implies that majority of them are in a better position to be aware of, understand and adopt improved cowpea technologies. This is in tandem with the findings of Bashir et al. (2018) who opined that most of the respondents $(50 \%)$ had acquired one form of education or the other. They can easily understand and adopt innovation.

\section{Farm size}

The result further revealed that about $59.0 \%$ of the respondents cultivate less than 4 hectares of land. This implies that most of the farmers are small farm holders. This agrees with the findings of Sani et al. (2014), which revealed that a relatively small farm size could constitute a major constraint to technology adoption.

\section{Household size}

The above table revealed that majority $(58.0 \%)$ had between 6-10 persons. It implies that there will be enough hands to participate in farming operations despite the fact that cowpea production is labor intensive. It further indicates that $29.0 \%$ of the respondents have less than 5 members, $13.0 \%$ had between 11 - 15 members. Family labor is an important component for small-scale holders. This is mainly because small farm holders are resource poor and may have to depend on family labor for agricultural activities (Idrissa, 2009).

\section{Annual farm income}

The respondent's annual farm income revealed that $11.0 \%$ earn below N200, 000 while $51.0 \%$ representing most of the respondents earn between N201, 000 - N400, 000. Moreover, $20.0 \%$ of the respondents earned between N401, 000 - N600, 000 and only $18.0 \%$ earned greater than N601, 000. By implication, the respondents earned a reasonable income that will enable them to acquire improved cowpea production technologies at their disposal. This is in tandem with the findings of Ouma et al. (2006), which showed a positive relationship between farmers' level of income and adoption of innovations. This is partly because high level of income dispels fear of risk in the process of adoption of an innovation.

\section{Access to credit}

The result on access to credit revealed that only $11.0 \%$ of the respondents had access to credit while $81.0 \%$ which constitute majority of the respondents had no access to credit. This agrees with the findings of Ibrahim et al. (2016), which revealed that accessibility to credit allows farmers to purchase and obtain adoption materials such as improved seeds, fertilizers and pesticides which will ultimately encourage and enhance the adoption of improved cowpea technologies.

\section{Farming experience}

As indicated in Table 1, majority (73.0\%) of the respondents had 11-20 years of farming experience while 12.0 $\%, 9.0 \%$, and $6.0 \%$ had 1-10 years, 21-30 years and above 31 years of farming experience respectively. The mean farming experience was 25 years. This implies that, the farmers had a considerable and enough farming experienced to be able to understand and adopt improved technologies. The length of farming experience is an indicator for increasing agricultural productivity because it enhances rapid adoption of innovations. This is in agreement with the result of Sani et al. (2014) who stated that farming experience is an advantage for increasing farm productivity. So also, Ani et al. (2008) are of the opinion that farming experience of farmers to a large extent affects their managerial know-how.

\section{Access to extension agents}

Majority $(65.0 \%)$ of the respondents had no contact with the extension agents while $35.0 \%$ had contact with extension agents. The adoption of any given innovation by farmers is highly facilitated by the efforts of extension workers particularly during demonstration (Oladosu and Okunade, 2006). The implication of this finding is that the respondents were left with no option rather than to adopt the innovations on their own due to insufficient contact with the change agent which contributed immensely to low supply to settle the excessive demand of cowpea in Nigeria. This lack of farmers contact with extension agents negates the 
theoretical role extension agencies supposed to play in technology diffusion and adoption which may be due to inadequacy or insufficient logistics for the extension worker to reach the farmer or incompetency of the personnel to be conversant with technical aspect of the technology (Tijjani et al., 2015).

Table 1: Distribution of the Respondents on their Socio-economic Characteristics (n=100)

\begin{tabular}{|c|c|c|c|}
\hline Variables & Frequency (f) & Percentage (\%) & Mean $(\pi)$ \\
\hline \multicolumn{4}{|l|}{ Age } \\
\hline Below 20 & 2 & 2.0 & \\
\hline $21-30$ & 5 & 5.0 & \\
\hline $31-40$ & 80 & 80.0 & 20 \\
\hline $41-50$ & 6 & 6.0 & \\
\hline Above 51 & 7 & 7.0 & \\
\hline \multicolumn{4}{|l|}{ Gender } \\
\hline Male & 89 & 89.0 & \\
\hline Female & 11 & 11.0 & \\
\hline \multicolumn{4}{|l|}{ Marital Status } \\
\hline Married & 80 & 80.0 & \\
\hline Single & 9 & 9.0 & \\
\hline Divorced & 4 & 4.0 & \\
\hline Widowed & 7 & 7.0 & \\
\hline \multicolumn{4}{|c|}{ Educational Background } \\
\hline Informal & 48 & 48.0 & \\
\hline Primary & 35 & 35.0 & \\
\hline Secondary & 13 & 13.0 & \\
\hline Tertiary & 4 & 4.0 & \\
\hline \multicolumn{4}{|l|}{ Farm Size } \\
\hline $1-3$ & 59 & 59.0 & \\
\hline $4-6$ & 29 & 29.0 & \\
\hline $7-9$ & 8 & 8.0 & 25 \\
\hline $10>$ & 4 & 4.0 & \\
\hline \multicolumn{4}{|l|}{ Household Size } \\
\hline $0-5$ & 29 & 29.0 & \\
\hline $6-10$ & 58 & 58.0 & \\
\hline $11-15$ & 13 & 13.0 & 25 \\
\hline Above 16 & 0 & 0.0 & \\
\hline \multicolumn{4}{|c|}{ Annual Farm Income } \\
\hline$<200,000$ & 11 & 11.0 & \\
\hline $201,000-400,000$ & 51 & 51.0 & 25 \\
\hline $401,000-60,000$ & 20 & 20.0 & \\
\hline$>601,000$ & 18 & 18.0 & \\
\hline \multicolumn{4}{|l|}{ Access to Credit } \\
\hline Had access & 11 & 11.0 & \\
\hline No access & 81 & 81.0 & \\
\hline \multicolumn{4}{|c|}{ Years of Farming Experience } \\
\hline $1-10$ & 12 & 12.0 & \\
\hline $11-20$ & 73 & 73.0 & \\
\hline $21-30$ & 9 & 9.0 & 25 \\
\hline Above 31 & 6 & 6.0 & \\
\hline \multicolumn{4}{|c|}{ Access to Extension Workers } \\
\hline Yes & 35 & 35.0 & \\
\hline No & 65 & 65.0 & \\
\hline Total: & 100 & & \\
\hline
\end{tabular}

Source: Field Survey, 2020.

*Multiple responses 


\section{Rate of Adoption of Cowpea Production Technologies by Farmers}

The rate of adoption of cowpea production technologies among farmers are presented in Table 2, seed dressing/treatment account for $(26.0 \%)$ of the respondents followed by pesticides application which constitute $(24.0 \%)$ of the respondents. This is because the seed dressing/treatment and pesticide use are paramount in increasing cowpea yields due to the prone nature of insect attacks on cowpea. The result also revealed that $(20.0 \%)$ of the respondents adopt cowpea varieties, (12.0\%) adopt storage facilities, (10.0\%) adopt insect resistance cultivars while recommended spacing and seed rate recorded $(7.0 \%)$ and $(1.0 \%)$ of the respondents respectively. This agrees with the findings of Agwu (2000) who reported that cowpea production packages such as used of improved seed, herbicide, pesticides, seed treatment, and used of improved storage facility are prerequisite to increased in cowpea production. The rate of adoption of improved cowpea production technologies is increasingly imminent. These implies that farmers in the study area were aware of the existence of the technologies and are increasingly trying to adopt more in order to make better economic gain.

Table 2: Rate of Adoption of Cowpea Production Technologies

\begin{tabular}{|c|c|c|c|}
\hline Technologies & $\begin{array}{ll} & \text { Frequency } \\
\text { (f) } & \end{array}$ & Percentage $(\%)$ & Mean $(\pi)$ \\
\hline Cowpea varieties & 20 & 20.0 & \\
\hline Insect resistance & 10 & 10.0 & \\
\hline Seed rate & 1 & 5.0 & 25 \\
\hline Seed dressing/treatment & 26 & 26.0 & \\
\hline Recommended spacing & 7 & 3.0 & \\
\hline Pesticides & 24 & 24.0 & \\
\hline Storage facilities & 12 & 12.0 & \\
\hline
\end{tabular}

Source: field survey, 2020.

*Multiple responses

Tobit Regression Estimates of some selected Socio-economic Characteristics of Farmers on the Rate of Adoption of Cowpea Production Technologies

The Tobit regression estimate analyzed socioeconomic factors that influence rate of adoption of cowpea technologies by farmers in the study area. The socio-economic factors considered includes the following; age, gender, marital status, educational background, farm size, household size, annual farm income, access to credit, farming experience and access to extension agents. These are presented in Table 3.

\section{Age ( $\left.\mathbf{x}_{1}\right)$}

The coefficient of age based on the result of the analysis was positive and statistically significant at $1 \%$ level of significance. The positive coefficient of age means that there is significant relationship between age of the farmers and adoption of improved cowpea production technologies. This implies that age is a great factor that influences the rate of adoption of cowpea because it can either increase or decrease the probability of adoption of technologies. This finding are in tandem with the studies of Ikini et al. (1998) cited in Agwu (2004) which shows that age, farming experience and organizational participation significantly influenced adoption. The difference might be the type of technologies studied among other factors.

\section{Gender ( $\left.\mathbf{x}_{2}\right)$}

The coefficient of gender was negative and not statistically significant. This implies that gender is not a factor influencing adoption of cowpea production technologies in the study area. This agrees with the a priori expectation that irrespective of one gender he or she could adopt or reject improved cowpea production technologies.

\section{Marital status ( $\left.\mathbf{x}_{3}\right)$}

The result of the analysis shows that the relationship between the variables was not statistically significant in the study area. This implies that not only married couples do have responsibilities which could stimulate them to adopt the improved cowpea production technologies in order to enhance their output but rather all other categories are subjected to accept or reject the technology.

\section{Educational background $\left(\mathbf{x}_{4}\right)$}

The coefficient of educational level was found to be positive and statistical significant at $1 \%$ level of significance. The positive coefficient of educational background indicates that there is a direct relationship between the adoption of improved cowpea production technologies and educational status of the farmers. This implies that educational background of farmers is imminent due the fact that an increased in education result into an increased in the level of adoption among farmers. This agreed with a priori expectation that the higher the educational level the higher the level of adoption and low level of education of the farmers is a great barrier to adoption of a complex innovation. This finding agrees with the result of Ojo (2003) in which he observed that level of formal education attained by poultry farmers influences technical inefficiency in poultry production. Salau et al. (2010) reported that the logistic regression result indicates farmer's education, age, farm size and income to be strong and significant determinants of adoption.

\section{Farm size ( $\left.x_{5}\right)$}

The coefficient of farm size was positive and statistically significant at $5 \%$ level of significance. The positive coefficient 
implies a significant relationship between the variables in the sense that as farm size increases, adoption of cowpea production technologies increase and vice-versa. In other word, the larger the farm size the higher the potential of adoption, these agree with the a priori expectation that large scale farmers which we often referred to as innovators in comparison to small scale farmers adopt improved technologies at a faster rate. The result was in conformity with the findings of Salasya et al. (2007) who stated that most of the small holder farmers having less hectares of farm land can hardly afford the improved farm technologies. Small scale farmers live at subsistence level which may discourage them from adopting improved technologies partly because of their capabilities. Isibor and Ugwumba (2014) applied logistic regression model in their study and found out that farm size, educational level and annual farm income were positively significant to adoption of oil palm production technologies.

\section{Household Size ( $\left.\mathbf{x}_{6}\right)$}

The coefficient of household size was positive and statistically significant at $1 \%$ level of significance. This agrees with the a priori expectation, that large household size could supply family labor which positively enhances adoption of cowpea production technologies in the study area.

\section{Annual Farm Income ( $\left.\mathbf{x}_{7}\right)$}

The coefficient of annual farm income was found to be significant at $10 \%$ and positively relates to adoption of cowpea production technologies by farmers in the study area. This implies that the higher the income of farmers, the higher the level of adoption of cowpea production technologies. This is because one of the major constraints to adoption of an innovation by farmers lies on their level of income which hindered their ability to procure or access adoption material. This result is in agreement with the studies conducted by Ouma et al. (2006); Agbamu (2006) which revealed that there is a positive relationship between farmers annual farm income and adoption of innovations.

\section{Access to Credit (x8)}

The result of access to credit was found to be not statistically significant and negatively influences the level of adoption of cowpea production technologies by farmers. This implies that majority of the farmers, who had access to credit facilities, had less probability of adoption of cowpea production technologies. This could be as a result of their economic situation and family demand that may prevent their likelihood to procure the technologies. This study is contrary to the findings of Beckmann et al. (2006) who observed that farming households who had access to credit has higher probability of adoption of improved technologies than those that do not have access.

\section{Farming Experience ( $\mathbf{x 9}$ )}

The result of the analysis further revealed that years of farming experience was found to be significant in influencing the likelihood of adoption of cowpea production technologies. The variable was found to be statistically significant at 5\% level of significance. This implies that farmers in the study area had a reasonable years of farming experience that influences their decision to try out new innovations more than their counterpart who has less experience and do fear changes that could lead to possible risk of failure. Years of farming experience could enable the farmers to have courage in adopting the technology as it was confirmed by the a priori expectation. This is in agreement with the findings of Bashir et al. (2018) which revealed that the variable was statistically significant at $1 \%$ level and positively related with likelihood of adoption. The years of farming experience influence the adoption of the technologies.

\section{Access to Extension Agents (x10)}

The coefficient of access to extension agents based on the analysis was negative and significantly related to adoption at $10 \%$ level of significance. This implies that farmers need to maintain sound contact with extension agents in order to obtained relevant information on improved or new technologies. These could have significant effect on the level of adoption of farmers. The study supported the findings of Rahman (2003), who reported that frequent extension visits or contact with farmers increases their likelihood of adoption of an innovation.

\section{Table 6: Tobit Regression Analysis of some selected Socio-economic Characteristics of Farmers on the Adoption of Cowpea} Production Technologies

\begin{tabular}{llll}
\hline Variables & \multicolumn{1}{c}{ Coefficien } & $(\mathbf{t})$ & $\mathbf{p}>|\mathbf{t}|$ \\
\hline $\mathrm{X}_{1}$ & $\mathbf{t}$ & 0.50 & \\
$\mathrm{X}_{2}$ & 0.119036 & -0.08 & $0.0016^{* * *}$ \\
$\mathrm{X}_{3}$ & -0.023008 & 0.44 & $0.1256 \mathrm{NS}$ \\
$\mathrm{X}_{4}$ & 6.076718 & 0.16 & $0.6579 \mathrm{NS}$ \\
$\mathrm{X}_{5}$ & 21.026517 & 0.23 & $0.0016^{* * *}$ \\
$\mathrm{X}_{6}$ & 10.0196631 & 0.09 & $0.0022^{* *}$ \\
$\mathrm{X}_{7}$ & 9.019533 & 2.13 & $0.0004^{* * *}$ \\
$\mathrm{X}_{8}$ & 0.8038 & 1.99 & $0.034^{*}$ \\
$\mathrm{X}_{9}$ & 1.4285 & 0.32 & $1.429 \mathrm{NS}$ \\
$\mathrm{X}_{10}$ & 0.053827 & 0.029 & $0.0058^{* *}$ \\
\hline
\end{tabular}

Source: field survey, 2020.

$* * * 1 \%$ level of significant

** $5 \%$ level of significant

$* 10 \%$ level of significant 
NS: Not statistically significant

\section{CONCLUSION}

Based on the findings of the study, majority of the farmers were middle-aged and averagely literate, implying that, many of them are in a position to be aware, understand and adopt cowpea production technologies available at their disposal. It is expected that the study will serve as a basis for extension workers and other actors in the agricultural value chain to positively adopt cowpea production technologies. The rate of adoption of cowpea production technologies was encouraging. The variable which significantly influenced the adoption of the cowpea production technologies were age, educational background, farms size, household size, annual farm income and years of farming experiences. The study concluded that there are a lot of constraining factors that interfere with adoption of the innovations despite the fact that there is an increase in the adoption process. These call for the need to employ the use of effective extension technique as well as policies that will significantly increase cowpea production in the study area and Nigeria at large.

\section{RECOMMENDATION}

Based on the findings of the study, the following recommendations were made:

i. Farmers should be encouraged to form cooperatives in order to ease their access to various interventions and procurement of agricultural input and services.

ii. Frequent supervision should be carried out by the change agent to ensure proper utilization and adoption of the technologies.

iii. Extension personnel should employ the use of effective extension teaching methods in the process of diffusion of an innovation to ensure adequate rate of adoption of cowpea production technologies.

iv. Government should implement policies that will enable farmers to have an enabling environment free from any treat to carry out their farming operations effectively.

\section{REFERENCES}

[1] Abah, D. and Tor, I. E. (2012). Cost and Returns of Cowpea Enterprise in Lafia Local Government Area, Nasarawa State, Nigeria. Patnsuk Journal, 8 (2): 59-67.

[2] Agbamu, J. U. (2006). Essentials of Agricultural Communications in Nigeria. First Edition, Malt-house Press Limited Lagos, Nigeria. Pp. 47-81.

[3] Agwu, A. E. (2000). Diffusion of Improved Cowpea Production Technologies among Farmers in the North East Savanna Zone of Nigeria. Department of Agricultural Extension, University of Nigeria, Nsukka. University of Nigeria Research Publications, Nsukka. Pp. 166.

[4] Agwu, A. E. (2004). Factors affecting Adoption of Improved Cowpea Production Technologies in Nigeria. International Journal of Agricultural Extension and Education, 11(1): 81-88.

[5] Ani, A. O. (2013). Contemporary issues in Programme Planning, Implementation, Monitoring and Evaluation in Agricultural Extension. Wright Integrated Publisher Limited Ibadan, Nigeria. Pp 176.189

[6] Ani, A. O., Ogunbameru, B. O. and Undiandeye, U. C. (2008). Factors Affecting Adoption of Agricultural Technology: In Ogunbameru, B. O., Undiandeye, U. C. and Ani, A. O. (eds.) Agricultural Extension Methodologies. Loud Books Publishers Ibadan, Nigeria.
[7] Asiabaka, C. C., Morse, S. and Kenyon, L. (2006). The Development, Dissemination and Adoption of Technologies Directed at Improving the Availability of Clean Yam Planting Material in Nigeria and Ghana. Report of a Study Mission Commissioned by U.K DFID, Crop Production Program (CPP), 11-22 June, 2006.

[8] Bashir, M. B., Ndaghu, A. A., Nakwe, S. H. G., Abdulazeez, A. W. and Samuel, R. T. (2018). Adoption of Cowpea Production Technologies among Farmers in Taraba State, Nigeria. IOSR Journal of Agriculture and Veterinary Science (IOSR-JAVS), 11 (3): 37-46.

[9] Beckmann, V., Irawan, E. and Wesseler, J. (2006). The Effect of Farm Labor Organization on Integrated Pest Management (IPM) Adoption: Empirical Evidence From Thailand, Contributed Paper Presented at Agricultural Economics Conference, Gold Coast, Australia, 12-18 August, 2006.

[10] Food Agriculture Organization (FAO), (2014). How to grow Good Cowpea Crop Nigeria.http://www.fao.org/sd/erp/toolkit/books/cowpea_illust_guidebook.p df.Accessed June,2014.en.wikipedia.org/wiki/mi Nigeria.

[11] Google map, https://www.google.com/search?q=damaturu+map+indicating+damaturu

[12] Ibrahim, A. A., Waba, S. Y., Mohammed, N., and Mustapha, S. B. (2016). Factors Influencing the Level of Adoption of Cowpea Production Technologies in Askira/Uba Local Government Area of Borno State, Nigeria. International Academic Journal of Innovative Research, 3 (9): 1523.

[13] Idrisa, Y. L. (2009). Analysis of the Determinant of Soybean Production Technology Adoption by Farmers in Southern Borno, Nigeria. Unpublished Ph.D. Thesis submitted to the Department of Agricultural Economics and Extension Services, University of Maiduguri, Nigeria.

[14] International Institute of Tropical Agriculture (IITA), (2009). Cowpea Project for Africa Research and Development. Available at: $\mathrm{http} / / \mathrm{www}$.iita.org/crop/cowpea.

[15] Ikini, E. I., Annatte, A. I. Umaru, M., and Jegede, O. C. (1998). Study of Extent of Adoption of Cockeret Exchange Technology (CET) by Rural Farmers in Adamawa State, Nigeria. Proceedings of the Siver Anniversary Conference of the Nigeria Society for Animal Production (NSAP), 21-26 March, 1998.

[16] International Institute of Tropical Agriculture (IITA), (2006). Research for Development. Cereals and Legumes Systems: Cowpea.

[17] Isibor, A. C. and Ugwumba, C. O. A. (2014). Adoption of Oil Palm Production Technologies in Ihiala Local Government of Anambra State, Nigeria. Journal of Agriculture and Veterinary Science, 6 (2): 1-8.

[18] Izge, A. U., Odo, P. E. and Dugje, I. Y. (2009). Arable Crop Production, Origin and Distribution of Cowpea. Published by DAA Press Limited, Kaduna, Nigeria.

[19] National Population Commission (NPC), (2006). Nigerian Population Commission, Abuja. Population of Nigeria by State and Sex, 1991 and 2006, Network. Retrieved 2008.

[20] Ojo, S. O. (2003). Productivity and Technical Efficiency of Poultry Egg Production in Nigeria. International Journal of Poultry Science, 2 (6): 459464.

[21] Oladosu I. O. and Okunade E. O. (2006). Perceptions of Village Extension Agents in Disseminating Agricultural Information in Oyo Agricultural Zone, Oyo State, Nigeria. Journal Social Science, 12 (13): 187-191.

[22] Ouma, J. O., De Groot, H. and Owuor, G. (2006). Determinants of Improved Maize Seed and Fertilizer Use in Kenya: Policy Implication. Paper Presented at the International Association of Agricultural Economists' Conference, Gold Cost, Australia,12-18 August, 2006.

[23] Paramu, S. and Ning, N. Q. (2017). Origin, Taxonomy, and Morphology of Vigna unguiculata (L.) Walp. In: Singh B. B., Mohan, D. R., Dashiel, K. E. and Jackai, L. E. N. (eds.). Advances in Cowpea Research. Co-publication of International Institute of Tropical Agriculture (IITA) and Japan International Research Center for Agricultural Sciences (JIRCAS), Ibadan, Nigeria. Pp. 1-12.

[24] Rahman, S. (2003). Profit Efficiency among Bangladesh Rice Farmers Journal of Food Policy, 2 (8): 483-503.

[25] Salasya, B., Mwangi, W., Mwabu, D. and Diallo, A. (2007). Factors Influencing Adoption of Stress-tolerant Maize Hybrid (WH502) In Western Kenya. African Journal of Agricultural Research, 2 (10): 544-551. 
[26] Salau, B. (2010). Assessing Adoption level of Diffused Light Storage Technology Among Irish Potato Farmers in Jos South Local Government Area, Plateau State. Unpublished M. Sc. Dissertation, Department of Agricultural Extension, University of Jos.

[27] Sani, A., Abubakar, B. Z, Yakubu, D. H., Atala, T. K. and Abubakar, L. (2014). Socio-economic Factors Influencing Adoption of Dual-purpose Cowpea Production Technologies in Bichi Local Government Area of Kano State, Nigeria. Asian Journal of Agricultural Extension Economics and Sociology, 11 (3): 258-273.

[28] Singh, B. B., Chambliss, O. L., Sharma, B. (1997). Recent Advances in Cowpea Breeding (PDF). In: Singh, B. B., Mohan, D. R., Dashiell, K. E. and Jackai, L. E. N. (eds.). Advances in Cowpea Research. Co-publication of International Institute of Tropical Agriculture (IITA) and Japan International Research Center for Agricultural Sciences (JIRCAS), Ibadan, Nigeria. Pp. 1-12.

[29] Tiamiyu, S. A., Adagba, M. A., Ibrahim, P. A. and Shaahu, A. (2013). Profitability of Sesame Production and Marketing in Nigeria. Advanced Journal of Agricultural Research, 1 (6): 88-094.

[30] Tijjani, A. R., Nabinta, R. T. and Muntaka, M. (2015). Adoption of Innovative Cowpea Production Practices in Rural Area of Katsina State, Nigeria. Journal of Agricultural and Crop Research, 3 (4): 53-58.

[31] Yindau, J. J. (2014). Factors Influencing the Adoption of Improved Agricultural Technology among Women Farmers in Mayo-Belwa Zone, Adamawa State, Nigeria. Unpublished M. Sc. Dissertation, Department of Agricultural Economics and Extension, Modibbo Adama University of Technology, Yola, Adamawa State, Nigeria.

\section{AUTHORS}

First Author - Mohammed, N, Department of Agricultural Technology, Yobe State College of Agriculture, Science and Technology Gujba, Nigeria

Second Author - Abubakar, M. I, National Agricultural Extension and Liaison Services, Ahmadu Bello University Zaria, Nigeria

Third Author - Abdul'aziz, M. A, Department of Basic Science Technology, Yobe State College of Agriculture, Science and Technology Gujba, Nigeria

Fourth Author - Kolo, M. K, Department of Agricultural Technology, Yobe State College of Agriculture, Science and Technology Gujba, Nigeria

Third Author - Saje, A. B, Department of Agricultural Technology, Yobe State College of Agriculture, Science and Technology Gujba, Nigeria

Correspondence Author - Nuruddeen Mohammed, E-mail: nuruddeenmb88@gmail.com, Mobile Phone: 08036003683 